Acta vet. scand. $1977,18,293-299$.

From the Parasitological Research Group of the Danish Agricultural and Veterinary Research Council, Royal Veterinary and Agricultural University, Copenhagen, Denmark.

\title{
RECOVERY OF INFECTIVE 3RD STAGE LARVAE OF HAEMONCHUS CONTORTUS AND OSTERTAGIA OSTERTAGI BY MIGRATION IN AGAR GEL
}

By

William M. Mwegoha and Rolf Jess Jørgensen

\begin{abstract}
MWEGOHA, WILLIAM M. and ROLF JESS JØRGENSEN: $R e-$ covery of infective 3rd stage larvae of Haemonchus contortus and Ostertagia ostertagi by migration in agar gel. Acta vet. scand. 1977, 18, 293-299. - A laboratory technique is described for the recovery of Haemonchus contortus and Ostertagia ostertagi infective larvae by migration in agar gel. The addition of bile increased the recovery rate of the haemonchus larvae, but had a somewhat depressive effect on the number of ostertagia larvae recovered. Similarly, storage at $4^{\circ} \mathrm{C}$ lowered the yield of larvae of both species, compared to freshly harvested larvae. However, the recovery rates for both species were sufficiently high to recommend the technique for isolation of the infective stages from field samples.
\end{abstract}

Haemonchus contortus larvae; Ostertagia ostertagi larvae; recovery; agar gel; bile.

Quantitation of infective larvae from herbage has become an essential part of basic studies on the epidemiology of dictyocaulus and trichostrongylid infections. It provides important information about the contamination, distribution and seasonal occurrence of infective larvae in the field. This knowledge is needed for the development of better control measures against parasitic infections in grazing ruminants and for evaluation of new management systems.

One problem in the technique has been the lack of an efficient method for the extraction of the larvae from the pasture samples. 
Several methods have been reported (Taylor 1939, Parfitt 1955, Durie 1959, Donald 1967, Lancaster 1970). These techniques have been based mainly on two principles, firstly the specific gravity of the larvae (by flotation, sedimentation and centrifugation) and, secondly, the particle size of the larvae (by sieving). The recovery rates have varied and the main disadvantage, as mentioned by Jørgensen ( $1975 \mathrm{~b}$ ), is the fact that there is an overlapping in both the specific gravity and particle size of the parasite larvae and those of soil nematodes and debris. Other methods have depended on the activity of the larvae themselves for isolation (Taylor, Persson 1974). Attempts have also been made to modify the apparatus (Durie, Persson), but still the results were variable or the methods less suitable for routine purposes.

The following experiments were designed to observe the migration of trichostrongylid infective larvae in agar gel, employing the technique described by Jørgensen $(1975 \mathrm{~b}$ ) for the isolation of dictyocaulus larvae. The purpose was to study whether trichostrongylid larvae can migrate in agar gel similarly to dictyocaulus larvae (Jørgensen 1975 a) and whether the larvae can be recovered in sufficiently high percentage so that the method can be recommended for the examination of pasture samples for these parasitic larvae.

The experiments were carried out with and without the addition of ox bile to the agar gel. Bile was used for comparison of its effect on the rate of recovery, since bile has been shown to have a stimulatory effect on dictyocaulus larvae (Jørgensen 1973).

The experiments comprised pure laboratory cultures of Haemonchus contortus and Ostertagia ostertagi.

\section{MATERIALS AND METHODS}

\section{Haemonchus contortus}

Adult female haemonchus worms were isolated from sheep abomasa obtained at a slaughter-house in southern Jutland (Tønder), December 1974. The worms were crushed to release the eggs which were incubated at $26^{\circ} \mathrm{C}$ for eight days in sterile faeces mixed with sawdust. The third stage larvae were extracted by a modified Baermann technique (Henriksen 1965) and were tested either immediately or after storing in shallow water at $4^{\circ} \mathrm{C}$. 


\section{Ostertagia ostertagi}

Third stage larvae of these organisms were obtained by culturing faeces, as described above, from calves which were infected with a monoculture obtained at the State Veterinary Serum Laboratory.

The procedure and the material and apparatus described by Jorgensen $(1975 \mathrm{~b})$ for the isolation of dictyocaulus larvae were used in the present recovery experiments.

\section{Glass columns}

Glass columns with a total length of $385 \mathrm{~mm}$ were used. They consisted of a cylindrical part $305 \mathrm{~mm}$ long and $43 \mathrm{~mm}$ in diameter tapering to a pipe stub with an inner diameter of $2 \mathrm{~mm}$. The pipe stub was fitted with rubber tube and clamp. The tubes were kept vertically in racks.

\section{Trays}

Plastic trays with a smooth surface and plain bottom measuring $200 \times 300 \mathrm{~mm}$ were used.

\section{Experimental procedures}

Agar gel, $3 \%$, was prepared from Difco Bacto Agar and kept in a water bath at $50^{\circ} \mathrm{C}$. Ox bile was also prepared and kept in the same water bath.

Measured equal amounts of larval suspension were placed in six small counting dishes. The number of viable larvae in each dish was counted and the contents were transferred to $250 \mathrm{ml}$ beakers to which $40^{\circ} \mathrm{C}$ warm water was added to the level of $60 \mathrm{ml}$.

When freshly harvested larvae were tested, the method of counting live active larvae before processing was found to be difficult because of their fast movements and the procedure was therefore modified. In each dish of two parallel rows of 12 counting dishes $2 \mathrm{ml}$ of a uniform suspension of larvae were placed. Twelve of the dishes were processed for larval migration as described above (six with bile and six without bile), without counting. The other 12 were used for counting after killing the larvae with Lugols iodine. The mean number of larvae per dish was used in the calculations. 
A set of six glass columns was prepared with water at $40^{\circ} \mathrm{C}$. A $20 \mathrm{~cm}$ by $35 \mathrm{~cm}$ piece of cloth gauze was fixed in each of six plastic trays, corresponding to the number of samples for processing, by a fine spray of water.

Sixty $\mathrm{ml}$ of the liquid agar was mixed with $15 \mathrm{ml}$ of prewarmed bile and poured into each of three beakers. Similarly, $60 \mathrm{ml}$ of agar plus $15 \mathrm{ml}$ of water was poured into three beakers. All beakers with their contents were kept at $40^{\circ} \mathrm{C}$ until further processing. Each warm liquid agar mixture was then quickly mixed with a larval suspension and poured into a tray.

The agar mixture was left for 15 min., then the solid slab, approx. $2.5 \mathrm{~mm}$ thick, was lifted from the tray, held hanging vertically, and wound into a roll which was then submerged in water in a glass column. Incubation took place at $38^{\circ} \mathrm{C}$ overnight.

Approx. $10 \mathrm{ml}$ of fluid was drawn off into conical centrifuge tubes from each column and centrifuged at 2,000 r.p.m. for 2 min. The supernatant was syphoned off and the larval sediment transferred to counting dishes. Drops of Lugols iodine were added to each dish; they were left for about $1 \mathrm{hr}$. and then discoloured by sodium thiosulphate. The third stage infective larvae retained the red iodine stain because of their thick cuticle through which diffusion apparently takes place at a very low rate. The recovered larvae were counted under the stereomicroscope.

\section{RESULTS}

The results are presented in Tables 1, 2 and 3. It appears that the infective larvae of both species were capable of migration in agar gel since a large proportion could be recovered.

Table 1 shows that an average of $53.5 \%$ (range $46-59 \%$ ) of old haemonchus larvae were recovered when processed without bile. The addition of bile consistently increased the recovery rate resulting in a mean recovery of $81.5 \%$ (range $67-90 \%$ ).

Table 2 shows that freshly harvested third stage haemonchus larvae could be recovered in comparably high numbers even without the addition of bile ( $72 \%$ ), probably due to a higher level of spontaneous motility in these larvae. When larvae were stored for six days, the recovery rate was found to be comparable to that of the old larvae.

Table 2 also shows that as many as $\mathbf{9 0} \%$ of freshly harvested infective larvae of Ostertagia ostertagi were recovered without 
the addition of bile, and that the addition of bile lowered the recovery rate by $20 \%$. Storage of larvae for six days as well as for more than six months (Table 3 ) lowered the recovery rates. The effect of bile remained slightly depressive.

Table 1. Recovery of old Haemonchus contortus larvae. Larvae stored at $4^{\circ} \mathrm{C}$ for more than 6 months.

\begin{tabular}{|c|c|c|c|c|c|c|}
\hline \multirow[b]{2}{*}{ Trial } & \multicolumn{3}{|c|}{ Agar gel with bile } & \multicolumn{3}{|c|}{ Agar gel without bile } \\
\hline & $\begin{array}{c}\text { number } \\
\text { added }\end{array}$ & $\begin{array}{c}\text { number } \\
\text { recovered }\end{array}$ & $\begin{array}{c}\% \\
\text { recovered }\end{array}$ & $\begin{array}{l}\text { number } \\
\text { added }\end{array}$ & $\begin{array}{c}\text { number } \\
\text { recovered }\end{array}$ & $\begin{array}{c}\% \\
\text { recovered }\end{array}$ \\
\hline \multirow{4}{*}{1} & 44 & 26 & 59 & 44 & 18 & 41 \\
\hline & 34 & 22 & 65 & 35 & 16 & 46 \\
\hline & 52 & 40 & 77 & 35 & 18 & 51 \\
\hline & \multicolumn{2}{|c|}{ Mean recovery } & $67 \%$ & \multicolumn{2}{|c|}{ Mean recovery } & $46 \%$ \\
\hline \multirow{4}{*}{2} & 152 & 140 & 92 & 112 & 65 & 58 \\
\hline & 229 & 189 & 83 & 162 & 72 & 44 \\
\hline & 185 & 176 & 95 & 142 & 72 & 51 \\
\hline & \multicolumn{2}{|c|}{ Mean recovery } & $90 \%$ & \multicolumn{2}{|c|}{ Mean recovery } & $51 \%$ \\
\hline \multirow{4}{*}{3} & 95 & 75 & 79 & 100 & 59 & 59 \\
\hline & 106 & 90 & 85 & 109 & 67 & 61 \\
\hline & 80 & 70 & 88 & 93 & 53 & 57 \\
\hline & \multicolumn{2}{|c|}{ Mean recovery } & $84 \%$ & \multicolumn{2}{|c|}{ Mean recovery } & $59 \%$ \\
\hline \multirow{4}{*}{4} & 102 & 78 & 77 & 115 & 57 & 50 \\
\hline & 96 & 82 & 85 & 116 & 83 & 72 \\
\hline & 110 & 102 & 93 & 90 & 48 & 53 \\
\hline & \multicolumn{2}{|c|}{ Mean recovery } & $85 \%$ & \multicolumn{2}{|c|}{ Mean recovery } & $58 \%$ \\
\hline
\end{tabular}

T a b l e 2. Recovery of young 3rd stage larvae. Mean figures $\pm s$ of six determinations.

\begin{tabular}{|c|c|c|c|c|c|}
\hline \multirow{3}{*}{$\begin{array}{c}\text { Age } \\
\text { (number of } \\
\text { days stored } \\
\text { at } 4^{\circ} \mathrm{C} \text { ) }\end{array}$} & \multirow{3}{*}{$\begin{array}{c}\text { Initial } \\
\text { number } \\
\text { of } \\
\text { larvae }\end{array}$} & \multicolumn{4}{|c|}{ Larvae recovered in agar gel } \\
\hline & & \multicolumn{2}{|c|}{ with bile } & \multicolumn{2}{|c|}{ without bile } \\
\hline & & $\begin{array}{c}\text { number } \\
\text { recovered }\end{array}$ & $\begin{array}{l}\text { mean } \\
\text { recovery } \%\end{array}$ & $\begin{array}{l}\text { number } \\
\text { recovered }\end{array}$ & $\begin{array}{l}\text { mean } \\
\text { recovery } \%\end{array}$ \\
\hline \multicolumn{6}{|c|}{ Haemonchus contortus } \\
\hline 0 & $82 \pm 9$ & $70 \pm 10$ & 85 & $60 \pm 13$ & 72 \\
\hline 6 & $103 \pm 6$ & $72 \pm 5$ & 70 & $44 \pm 5$ & 43 \\
\hline \multicolumn{6}{|c|}{ Ostertagia ostertagi } \\
\hline $\mathbf{0}$ & $64 \pm 10$ & $46 \pm 7$ & 70 & $59 \pm 13$ & 90 \\
\hline 6 & $116 \pm 7$ & $75 \pm 7$ & 65 & $87 \pm 11$ & 75 \\
\hline
\end{tabular}


T a b le 3. Recovery of old Ostertagia ostertagi larvae. Larvae stored at $4^{\circ} \mathrm{C}$ for more than 6 months. Mean figures $\pm \mathrm{s}$ of 12 determinations.

\begin{tabular}{|c|c|c|c|c|c|}
\hline \multirow[b]{3}{*}{ Trial } & \multirow{3}{*}{$\begin{array}{c}\text { Initial } \\
\text { number } \\
\text { of } \\
\text { larvae }\end{array}$} & \multicolumn{4}{|c|}{ Larvae recovered in agar gel } \\
\hline & & \multicolumn{2}{|c|}{ with bile } & \multicolumn{2}{|c|}{ without bile } \\
\hline & & $\begin{array}{l}\text { number } \\
\text { recovered }\end{array}$ & $\begin{array}{l}\text { mean } \\
\text { recovery \% }\end{array}$ & $\begin{array}{l}\text { number } \\
\text { recovered }\end{array}$ & $\begin{array}{c}\text { mean } \\
\text { recovery } \%\end{array}$ \\
\hline 1 & $69 \pm 11$ & $32 \pm 5$ & 47 & $36 \pm 7$ & 52 \\
\hline 2 & $66 \pm 6$ & $28 \pm 7$ & 43 & $36 \pm 6$ & 55 \\
\hline 3 & $78 \pm 12$ & $31 \pm 8$ & 41 & $55 \pm 11$ & 71 \\
\hline
\end{tabular}

\section{DISCUSSION}

It is interesting to note that the addition of bile increased the recovery rate of the Haemonchus contortus larvae, but somewhat lowered the recovery rate of the Ostertagia ostertagi larvae. The reason for this difference in response between the infective stages of these two abomasal parasites is unknown.

Despite the difference in response to bile and despite the differences in recovery rates, a sufficiently large proportion of the larvae are recovered to recommend the described technique for field use. Jørgensen ( $1975 \mathrm{~b}$ ) pointed out the advantages of isolating infective dictyocaulus larvae by migration in agar gel. With the present results it is concluded that the technique, with the addition of bile, is suitable for isolation of the infective stages of Ostertagia ostertagi, Haemonchus contortus, Dictyocaulus viviparus and Dictyocaulus filaria.

\section{REFERENCES}

Donald, D.: A technique for the recovery of strongyloid infective larvae from small sample units of pasture. J. Helminth. 1967, 41, $1-10$.

Durie, P. H.: A new technique for the recovery of infective strongyle larvae from soil and pasture. J. Helminth. 1959, 33, 180-196.

Henriksen, Sv. Aa.: En forbedret teknik ved undersøgelse for lungeormlarver i faeces. (An improved technique for the examination of faeces for larvae of lung worms). Nord. Vet.-Med. 1965, 17, $446-454$.

Jørgensen, $R$. J.: In vitro effect of bile on the motility of Dictyocaulus viviparus third stage larvae. Acta vet. scand. 1973, 14, 341-343.

Jørgensen, $R$. J.: In vitro migration of Dictyocaulus viviparus larvae: migration of the infective stage in agar gel. Int. J. Parasit. 1975 a, 5, 199-202. 
Jørgensen, $R$. J.: Isolation of infective Dictyocaulus larvae from herbage. Vet. Parasit. 1975 b, 1, 61-67.

Lancaster, M. B.: The recovery of infective nematode larvae from herbage samples. J. Helminth. 1970, 44, 219-230.

Parfitt, J. W.: Two techniques for the detection and enumeration of the larvae of Dictyocaulus viviparus in faeces and herbage. Lab. Pract. 1955, 4, 15-16.

Persson, L.: A modified Baermann apparatus for the recovery of infective nematode larvae from herbage and manure. $\mathrm{Zbl}$. Vet.Med. 1974, B, 21, 483-488.

Taylor, E. L.: Technique for the estimation of pasture infestation by strongylid larvae. Parasitology 1939, 31, 473-478.

\section{SAMMENDRAG}

Isolering af infektive tredie stadium larver af Haemonchus contortus og Ostertagia ostertagi ved hjælp af migration i agar gel.

En teknik baseret på migration $i$ agar gel indeholdende galde blev afprøvet med henblik på isolering af de infektive stadier af trichostrongyliderne Haemonchus contortus og Ostertagia ostertagi. Effekten af galdetilsætning og effekten af de anvendte larvers alder belyses. Galdetilsætning $\varnothing$ gede genfindelsesprocenten af haemonchus larverne, hvorimod effekten på ostertagia larverne var modsat, men mindre udtalt. Ligeledes fandtes lavere genfindelsesprocenter for larver af begge arter efter opbevaring ved $4^{\circ} \mathrm{C}$. Det konkluderes, at migration i agar gel vil kunne anbefales til isolering af infektive haemonchus og ostertagia larver fra feltprøver.

(Received February 28, 1977).

Reprints may be requested from: R. Jess Jørgensen, the Parasitological Research Group, Institute of Veterinary Microbiology and Hygiene, Royal Veterinary and Agricultural University, Bülowsvej 13, DK-1870 Copenhagen V, Denmark. 